\title{
Left main coronary artery stenting in a patient with acute coronary syndrome complicated by embolisation of the diagonal branch of the left descending artery. Intra-vessel ultrasound/virtual histology findings
}

\begin{abstract}
Angioplastyka pnia lewej tętnicy wieńcowej powikłana zatorowością gałęzi diagonalnej tętnicy zstępującej przedniej u chorej z ostrym zespołem wieńcowym bez uniesienia odcinka ST. Zastosowanie ultrasonografii wewnątrzwieńcowej/wirtualnej histologii
\end{abstract}

\author{
Aleksander Araszkiewicz, Maciej Lesiak, Marek Grygier, Stefan Grajek \\ $1^{\text {st }}$ Department of Cardiology, Poznan University of Medical Sciences, Poland
}

Post Kardiol Interw 2011; 7, 3 (25): 257-260 DOI: $10.5114 /$ pwki.2011.24745

\begin{abstract}
We present the case of a 44-year-old female patient with non-ST-elevation acute myocardial infarction treated with left main coronary artery (LMCA) angioplasty with stent implantation. The novel method of coronary artery imaging/virtual histology (IVUS/VH) was used to confirm the presence of thin cap fibroatheroma (TCFA) in LMCA. The procedure was complicated by occlusion of the diagonal branch with embolic material originating from the squized atherosclerotic plaque.
\end{abstract}

Key words: left main coronary artery, intra-vessel ultrasound, virtual histology, complications

\section{Streszczenie}

Przedstawiamy opis przypadku dotyczący 44-letniej kobiety z ostrym zawałem serca bez uniesienia odcinka ST, leczonej angioplastyką pnia lewej tętnicy wieńcowej. Wykorzystanie wirtualnej histologii (IVUS/VH) pozwoliło na identyfikację niestabilnej blaszki miażdżycowej (thin cap fibroatheroma). Procedura była powikłana zamknięciem gałęzi diagonalnej materiałem zatorowym pochodzącym prawdopodobnie z blaszki miażdżycowej w pniu lewej tętnicy wieńcowej.

Słowa kluczowe: pień lewej tętnicy wieńcowej, ultrasonografia wewnątrzwieńcowa, wirtualna histologia, powikłania

\section{Introduction}

Pathological studies have shown that necrotic rich core plaques at high risk of rupture - so-called thin cap fibroatheroma (TCFA) - are infrequently present in the left main coronary artery (LMCA), while they are common in the proximal segments of three main coronary arteries [1]. Similarly, angiographic studies as well as intra-vessel ultrasound analyses have observed that plaque rupture rarely occurs in the LMCA or distal part of coronary arteries, whereas it is far more common in the proximal part of coronary vessels, especially in the left anterior descending artery $[2,3]$. The reasons why vulnerable plaques tend to spare the LMCA are still poorly understood [4].

We present the case of a female patient with acute coronary syndrome caused by vulnerable plaque in LMCA confirmed by the novel method of coronary artery imaging/ virtual histology (IVUS/VH).

\section{Case report}

The 44-year-old woman, a regular smoker, presented with diffuse chest pain. The first anginal symptoms on exertion started 2 weeks earlier. Six h before admission she felt prominent chest discomfort at rest with severe 
apprehension. She had elevated cholesterol levels, and positive family history. On admission, she was haemodynamically stable; her blood pressure was $160 / 80 \mathrm{mmHg}$,

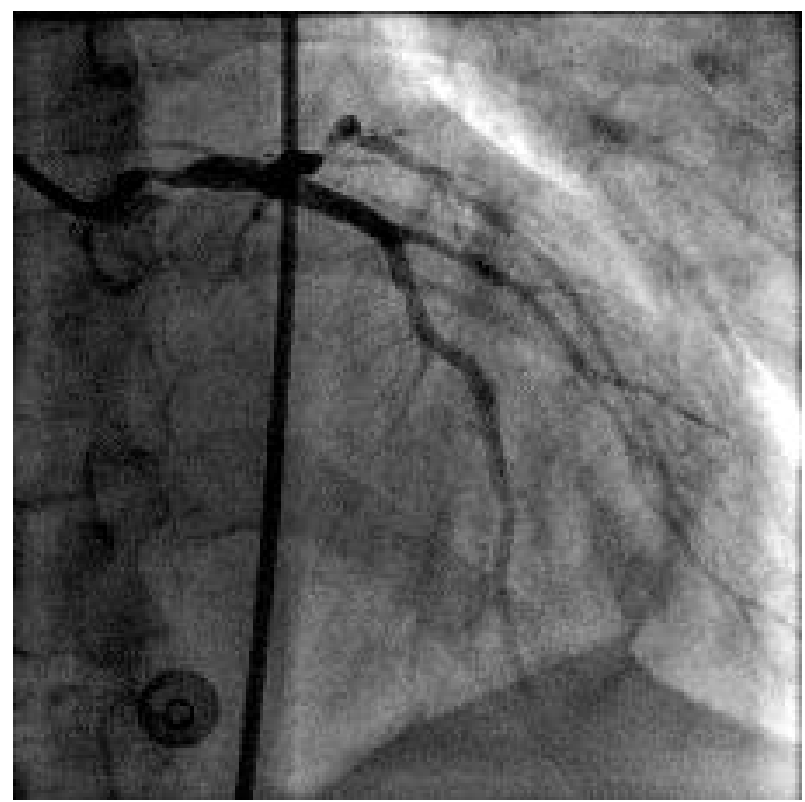

Fig. 1. Severe left main coronary artery (LMCA) stenosis. Occluded small postero-lateral branch of circumflex artery

Ryc. 1. Krytyczne zwężenie pnia lewej tętnicy wieńcowej. Zamknięta mała gałąź tylno-boczna tętnicy okalającej and the heart rate $75 / \mathrm{min}$. No symptoms of heart failure were observed. The electrocardiogram demonstrated normal sinus rhythm 75/min, ST-depressions in lead I, aVL, and negative T wave in lead V2-V5. The cardiac troponin I level was markedly elevated $(10.2 \mathrm{ng} / \mathrm{ml})$. Loading doses of clopidogrel (600 mg), and aspirin (300 mg) were given, and urgent coronary angiography was performed. It revealed LMCA stenosis and occluded small postero-lateral branch of the left circumflex artery (fig. 1). The dominant right coronary artery was without any significant lesions. The intravascular ultrasound examination (IVUS) was performed, to estimate the true LMCA diameter. The minimal lumen area was $4.2 \mathrm{~mm}^{2}$ (fig. $2 \mathrm{~A}$ ), and no symptoms of fresh thrombus were found. The virtual histology $(\mathrm{VH})$ analysis revealed a thin cap fibroatheroma, with a large necrotic core (32\%) and $12 \%$ of dense calcium (fig. 2 B). We decided to perform percutaneous coronary intervention of LMCA. A 0.014" guidewire was passed down the left anterior descending artery (LAD), and $4.0 \times 16 \mathrm{~mm}$ TAXUS Liberte (Boston Scientific, USA), paclitaxel-eluting stent was implanted, using the direct-stenting method. The stent was then post-dilated, with a $4.0 \times 12 \mathrm{~mm}$ noncompliant balloon, at the pressure of $22 \mathrm{~atm}$. On angiography no residual stenosis was revealed, and in IVUS, the MLA increased to $10.1 \mathrm{~mm}^{2}$.

After completion of the procedure the patient reported the recurrence of anginal pain. The electrocardiogram showed ST-segment elevations in leads I, aVL, V4-V6. Coronary angiography revealed no signs of thrombosis
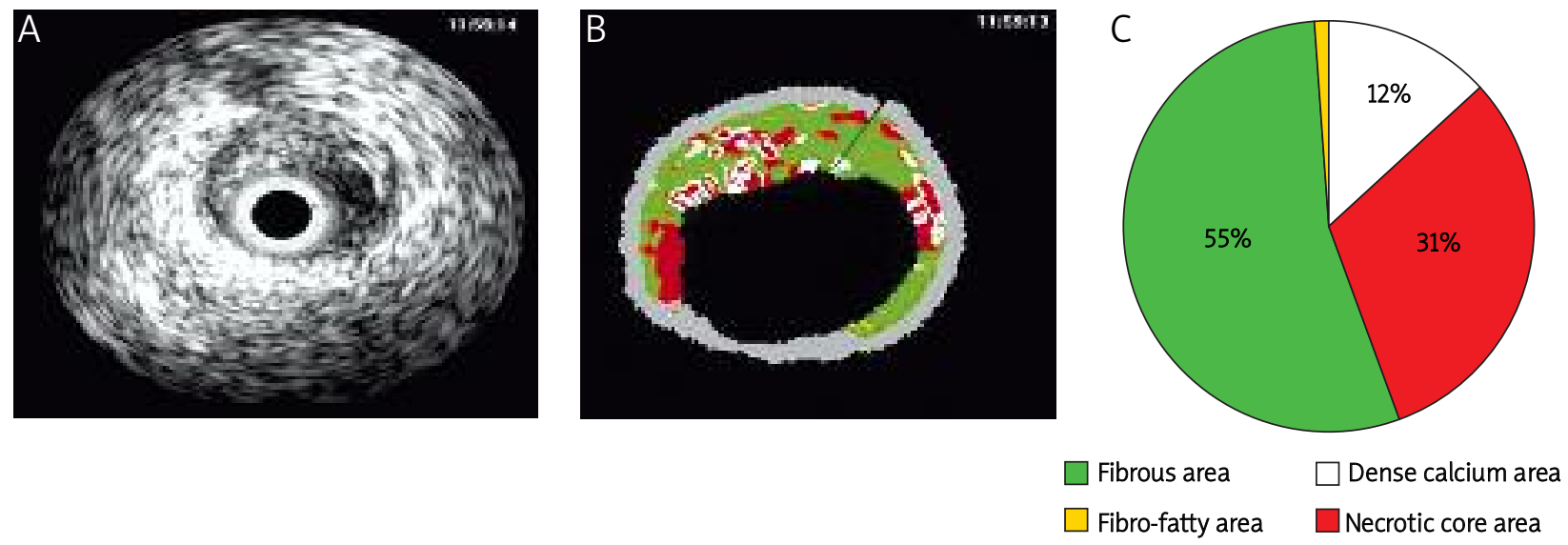

Fig. 2. A - intra-vessel ultrasound of LMCA. No signs of thrombosis. The minimal lumen area was $4.2 \mathrm{~mm}^{2}$. B - IVUS virtual histology of LMCA findings. The different plaque components were assigned colour codes. Calcified, fibrous, fibrolipidic and necrotic core regions were labelled white, green, greenish-yellow and red respectively. $\mathbf{C}$ - graph illustrates the percentage of components oh atherosclerotic plaque. Necrotic core (red) $-31 \%$, dense calcium (white) - 12\%, fibrous tissue area (green) - 55\%, fibro-fatty area (yellow) - 3\%

Ryc. 2. A - ultrasonografia wewnątrzwieńcowa pnia lewej tętnicy wieńcowej. Bez cech zakrzepicy. Minimalne pole powierzchni 4,2 mm². B - obraz pnia lewej tętnicy wieńcowej w wirtualnej histologii. Poszczególne składowe blaszki miażdżycowej oznaczono osobnymi kolorami: zwapnienia - kolor biaty, części włókniste - kolor czerwony, włóknisto-tłuszczowe - kolor żółty, martwicze - kolor czerwony. C - wykres ilustrujący zawartość procentowa poszczególnych składowych w blaszce miażdżycowej. Martwica (kolor czerwony) - 31\%, zwapnienia (kolor biały) - 12\%, tkanka włóknista (kolor zielony) - 55\%, tkanka włóknisto-tłuszczowa (kolor żótty) - 3\% 
within the implanted stent, but it showed occluded middle part of the large first diagonal branch (fig. 3). An intracoronary bolus of abciximab was administered, and then intravenous infusion was started. The lesion was crossed with a guidewire with difficulty, and balloon angioplasty was performed, with perfect angiographic results (no residual stenosis, TIMI 3 flow). After the procedure, the infusion of abciximab was continued for $12 \mathrm{~h}$. The patient also received unfractionated heparin, aspirin, clopidogrel, atorvastatin, metoprolol and ramipril. She responded well to the therapy. The peak troponin I level was $37.6 \mathrm{ng} / \mathrm{ml}$, and peak CK-MB 42 IU/l. Echocardiography showed left ventricular ejection fraction of $48 \%$ with akinesia of the lateral wall and hypokinesia of the anterior wall. She made an uneventful recovery. The patient was discharged 10 days later in good general condition, on aspirin, clopidogrel, atorvastatin, ramipril and metoprolol. After 9 months she was still asymptomatic and had no complaints.

\section{Discussion}

Left main coronary artery stenosis is the most challenging lesion in patients with acute coronary syndromes. Since the mass of myocardium at risk is very high, the patient is often in cardiogenic shock, and the risk of death is high. In the present case we decided to perform angioplasty of the left main coronary artery despite having on-site cardiac surgery. Coronary artery bypass grafting is currently the routine treatment for unprotected LMCA disease, but with the substantial progress in interventional techniques and equipment there is a growing body of evidence that LMCA lesions may be treated effectively and safely by interventionalists $[4,5]$. Our decision also resulted from the fact that the patient had non-ST-elevation acute myocardial infarction, with a prominent unstable plaque in LMCA requiring urgent revascularization. The presence of a dominant right coronary artery, without any significant changes, further reduced the risk of the procedure.

The novel method of coronary artery imaging - spectral analysis of IVUS radiofrequency, virtual histology (IVUS/VH) - was used in the presented case to measure the size of the vessel, as well as to confirm the presence of unstable plaque. The IVUS/VH data gave us the opportunity to obtain detailed quantitative information both on the overall plaque composition and the anatomical relation of specific plaque components to the lumen of the vessel [6]. We found a large extent of necrotic core and other elements of atherosclerotic plaque, as well as the presence of TCFA. The presence of TCFA, with large avascular, hypocellular lipid cores, makes the plaque very prone to rupture, which may result in epicardial artery occlusion, myocardial infarction and sudden cardiac death [1, 7].

In our case, although the stent was implanted without predilatation, the procedure was complicated by distal embolisation and occlusion of a large diagonal artery [8].

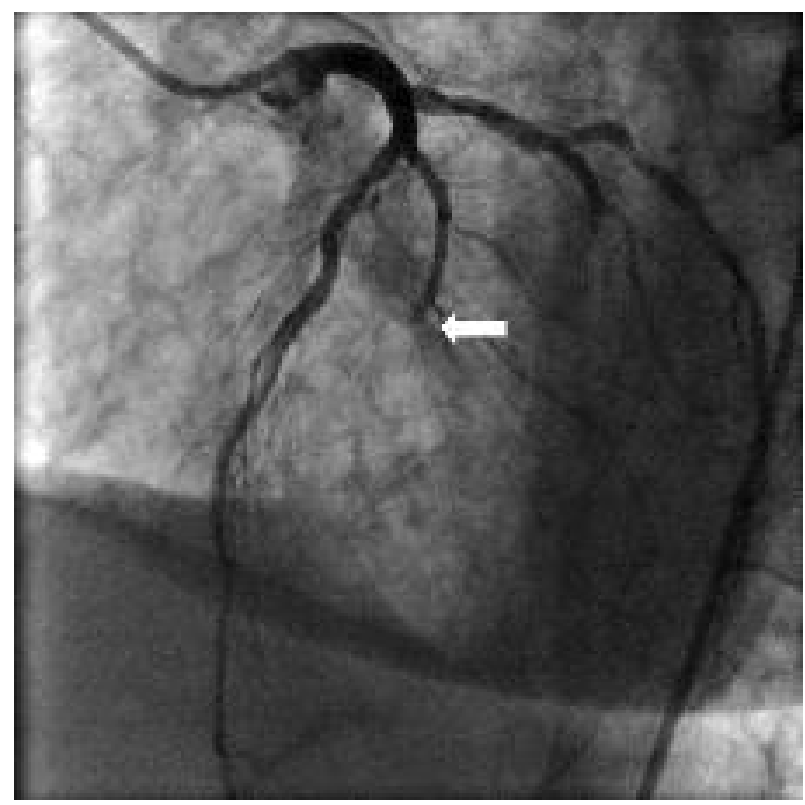

Fig. 3. White arrow - occluded diagonal branch of left descending artery. No signs of thrombosis in previously dilated LMCA

Ryc. 3. Biała strzatka - niedrożna gałąź diagonalna tętnicy zstępującej przedniej. Bez cech zakrzepicy we wcześniej wszczepionym stencie w priu lewej tętnicy wieńcowej

Since the occlusion was very difficult to cross, and no thrombus was found on baseline IVUS examination, it is highly probable that the embolic material was composed of the squized plaque. This rare but possible complication should always be taken into consideration while treating unstable patients, especially when the lesion is situated in a proximal part of a large vessel. We also advise evaluating the final angiogram after the procedure very carefully, to avoid overlooking the presence of distal embolisation. The administration of GP IIb/IIla receptor blockers may not be helpful in such cases, and the role of distal protection devices is yet to be established.

\section{References}

1. Kolodgie FD, Burke AP, Farb A, et al. The thin-cap fibroatheroma: a type of vulnerable plaque: the major precursor lesion to acute coronary syndromes. Curr Opin Cardiol 2001; 16: 285-292.

2. Wang JC, Normand SL, Mauri L, Konts RE. Coronary artery spatial distribution of acute myocardial infarction occlusions. Circulation 2004; 110: 278-284

3. Hong MK, Mintz GS, Lee CW, et al. The site of plaque rupture in native coronary arteries: a three-vessel intravascular ultrasound analysis. J Am Coll Cardiol 2005; 46: 261-265.

4. Buszman PE, Kiesz SR, Bochenek A, et al. Acute and late outcomes of unprotected left main stenting in comparison with surgical treatment. J Am Coll Cardiol 2008; 51: 538-545.

5. Lee Ms, Kapoor N, Jamal F, et al. Comparison of coronary artery bypass surgery with percutaneous coronary intervention with 
drug-eluting stents for unprotected left main coronary artery disease. J Am Coll Cardiol 2006; 47: 864-870.

6. Valqimiqli M, Rodriuez-Granillo GA, Garcia-Garcia HM, et al. Plaque composition in the left main stem mimics the distal but not the proximal tract of left coronary artery: influence of clinical presentation, length of the left main trunk, lipid profile, and systemic levels of C-reactive protein. J Am Coll Cardiol 2007; 49: 23-31.
7. Virmani R, Burke AP, Farb A, Kolodiqie FD. Pathology of the vulnerable plaque. J Am Coll Cardiol 2006; 47 (8 Suppl): C13-18.

8. Van Gaal WJ, West N, Banning AP. Myocardial infarction caused by distal embolisation of a ruptured left main plaque. Heart 2006; 92: 1101. 